Historic, Archive Document

Do not assume content reflects current scientific knowledge, policies, or practices. 



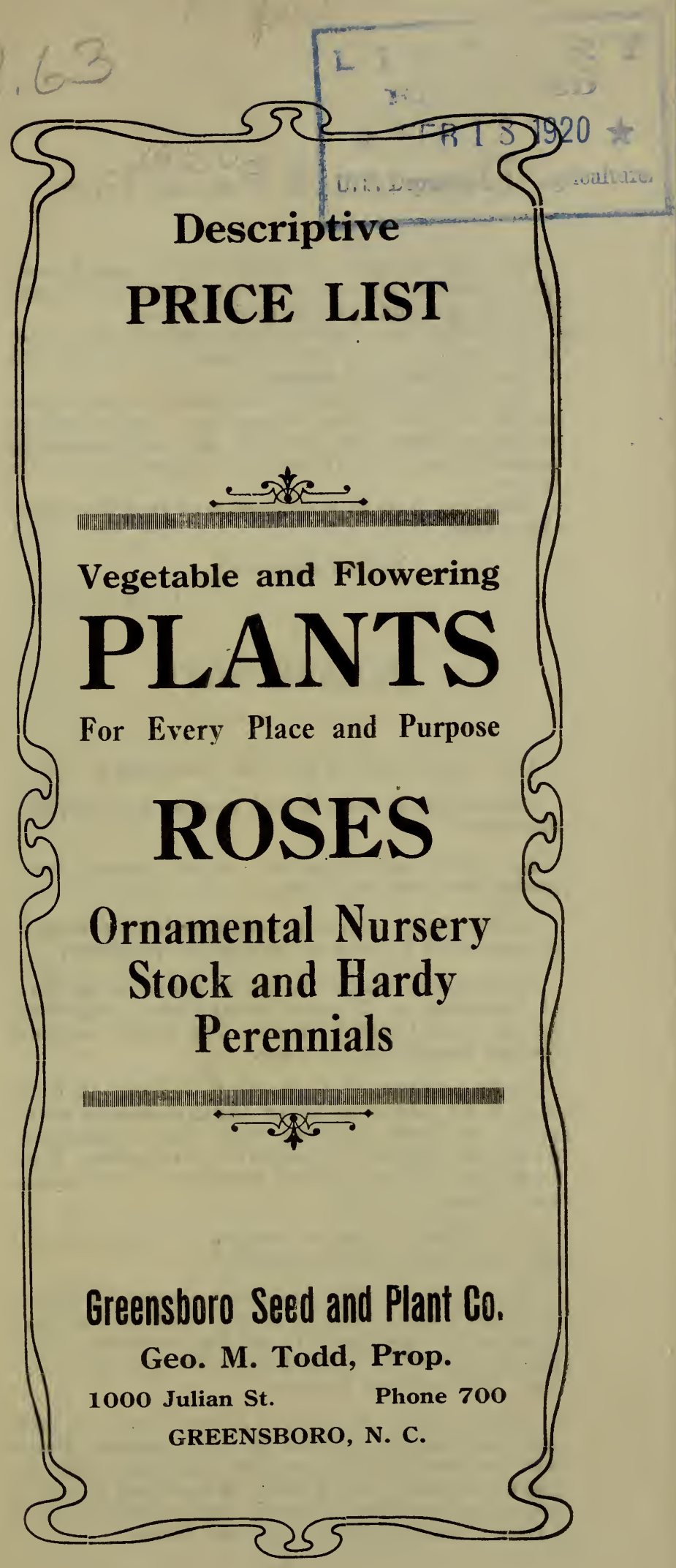




\section{Descriptive Price-List}

We take pleasure in presenting to our friends and customers our new catalogue, with our thanks for their generous patronage in the past.

Our collection includes those plants which are best suited to the Southern States and which will be sure to give good results.

We shall devote our best efforts to filling all orders to your entire satisfaction. The many encouraging words in the past will be incentive to greater effort in the future both in quality and liberality.

Thanking you in anticipation of your patronage this season.

Yours respectifully,

G. M. TODD

\section{PLEASE NOTE}

This list cancels all previous quotations.

Orders sent by mail should enclose full shipping directions.

All claims of whatsoever mature should be reported upon receipt of goods.

Orders from unknown correspondents should be accompanied by cash or satisfactory reference.

Remittances should be made either in the form of Postoffice or Express Money-Order, Registered Letter, Bank Draft or Check. For small amounts postage stamps may be used.

When remittance is made by check, 10 cents should be added to cover bank exchange on all points in North Carolina with the exception of Charlotte, Durham, Fayetteville, Greensboro, High Point. New Bern, Raleigh, Salisbury, Wilmington and Winston-Salem.

All orders are taken subject to being sold out and are filled in strict rotation.

We prefer to ship orders by express; they then trarel at a special rate of 20 per cent. lower than regular merchandise. It is not necessary that charges should be prepaid to secure this rate. We have the Southern Express.

When plants are ordered sent by mail and sufficient cash is not remitted to pay postage, plants will be sent for the amount remaining after the postage is paid. The postage on seed bed plants is about ten cents per hundred, and, on plants out of two-inch pots about ten cents per dozen. 


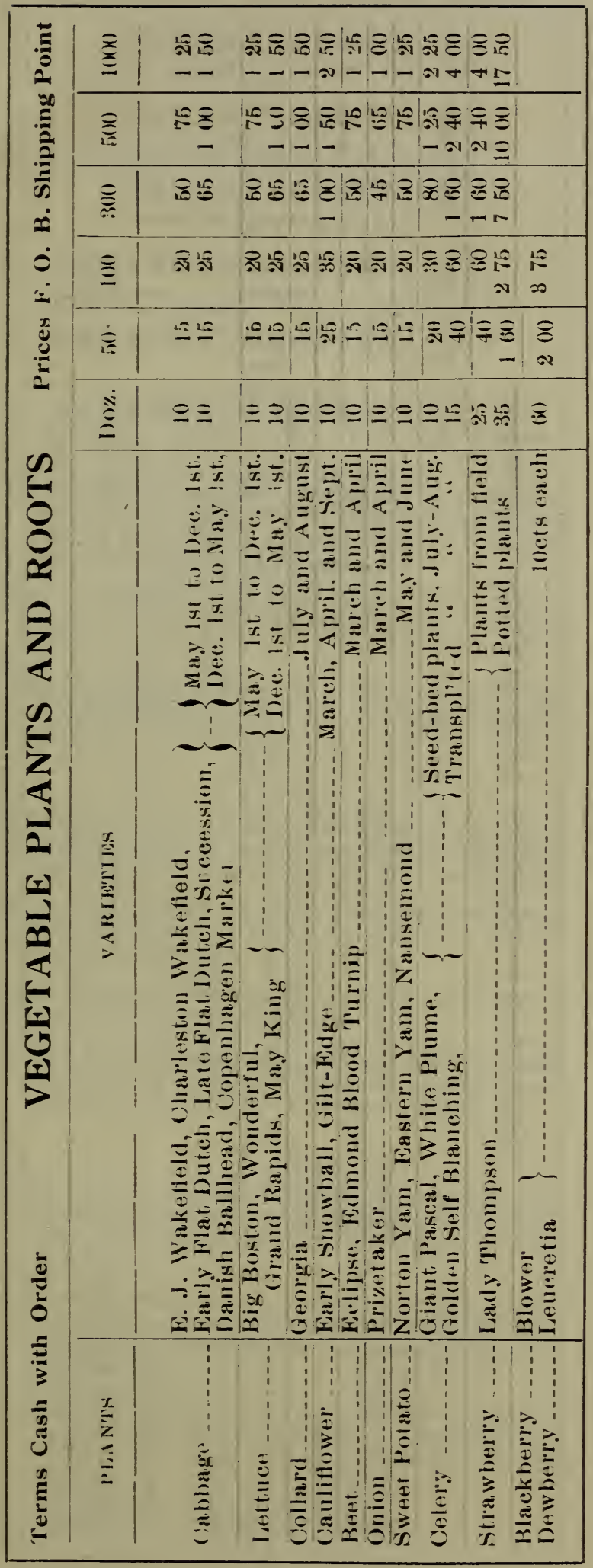




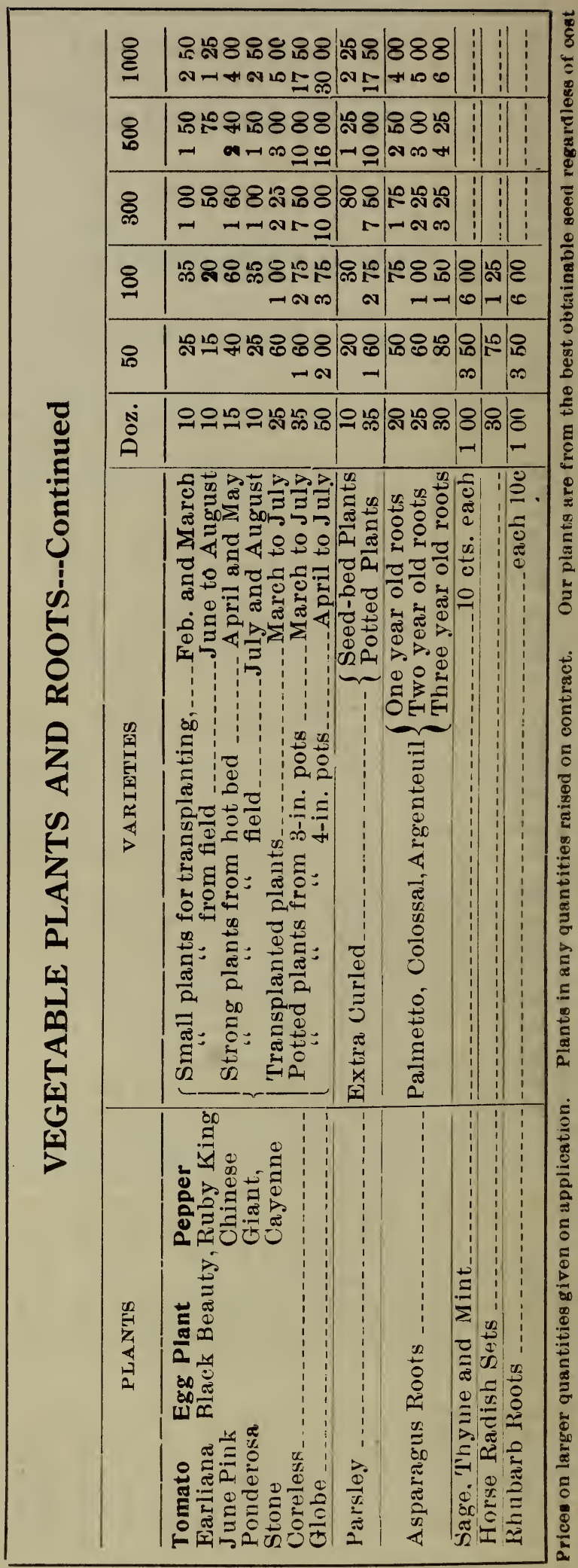




\title{
CHRYSANTHEMUMS
}

\author{
Standard Varietles
}

Named, 10c each, $\$ 1.00$ doz.; $\$ 8.00$ per 100

\section{White}

Early-Polly Rose-A fine white, of large size. One of the most desirable.

MId-Season-The Queen-Excels all in purity; $\theta x-$ tra large in size, of half globular form, with broad incurved petals; growth robust, with smooth, heavy, dark foliage.

Mrs. H. Robinson-Very popular. Flowers immense, incurving and broad petals of purest white.

Late-Timothy Eaton-An enormous, globular, Japanese, incurved variety of perfect form and growth. Color pure white.

\section{Yellow}

Mid-Season-Col. D. Appleton-Magnificent, Japanese, incurved with lower petals reflex and not showing center. Faultless stem and foliage.

Mrs. O. P. Bassett-Color a fine canary yellow of a soft texture. A large, flat incurved variety, with brosd petals.

Late-Golden Wedding-The grandest golden yellow variety ever introduced.

Yellow Eaton-Color, soft chrome yellow; a fine exsmple of the broad petaled, incurving Japanese type, showing no center; very large.

\section{Pink}

Early-Mrs. E. O. Hill-The finest extra early pink of the largest size. Broad, bold incurving flowers of an exquisite shade of light pink. $\mathbf{\Delta}$ good cut flower.

nid-season-Pink Ivory-Beautiful shell pink flowers of exquisite form and finish. Identical with ivory, the most popular of the white mumb, except in color.

W m. Duckham--Color a deep clear pink incurved with a broad petal, flower large, supported by a long stiff stem with good foliage; a strong grower.

Dr. Enguehard-Color a true pink. 


\section{Red}

John Shrimpton-Flowers of massive size, reflexed, broad petals; color a deep rich velvety crimson with no shade of brown or chestnut, heavy foliage which covers stem to flower.

\section{Lavender}

Lavender Queen-Immense solid flower, full and compact, outer petals reflexed, center erect, forming a flower of great depth; color a soft silvery lavender pink, very distinct; good grower, stiff stems and good foliage.

\section{Ostrich Plume Varieties}

Louis Boehmer-Pink Ostrich Plume. Very fine. L'enfant des deux Mondes-White Ostrich Plume. Monarch of Ostrich Plumes-Deep yellow.

\section{CANNAS}

Named varieties, 10c. each; $\$ 1.00$ per dozen, $\$ 7.50$ per 100. Mixed choice varieties, 50c. per dozen, $\$ 4.00$ per 100 , except where noted.

\section{Yellow Shades, Green Foliage}

Alsace-4 $\frac{1}{2}$ feet. Creamy white flowers. Blooms throughout the season in fine shapely plants. The nearest approach to a pure white variety.

Buttercup-4 feet. Pure yellow, very large, fine.

Florence Vaughn- $4 \frac{1}{2}$ feet. The most popular of all the yellows; flowers large; color golden yellow with bright red spots.

\section{Red Flowers, Green Foliage}

Black Prince-4 feet. A grand variety. Color, dark velvety maroon, almost black; red stems, dark green foliage edged with purple.

Charles Henderson-4 feet. Standard of excellence in crimson Cannas. Dark green foliage; color, brilliant crimson scarlet. One of the best reds for bedding.

Duke of Marlboro-5 feet. Beautiful crimson maroon. Sturdy and erect with metallic green foliage.

Mad. Crozy $-3 \frac{1}{2}$ feet. Flowers are of the brightest crimson scarlet. with a narrow golden yellow margin. A remarkably free bloomer. 
Queen Charlotte- $3 \frac{1}{2}$ feet. Color, bright orange, scarlet edged with canary yellow. Large flowers.

\section{Giant "Orehid Flowering"}

Austria-6 feet. The largest flowering Canna. Color. a pure canary yellow.

Italia-6 feet Enormous flowers of entirely distinct form. The color is bright scarlet, edged with golden yelluw. Foliage large and massive.

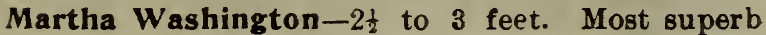
pink variety yet introduced. Color, a pure bright rose. A vigorous grower and a constant bloomer.

Mrs. Kathea Gray-6 feet. Best new up-to-date Cal. Canna. Uolor, a deep orange scarlet, overlaid with gold, yellow in the throat. Foliage a a bright glossy green.

Pennsylvania-6 feet. Flowers large, fully $6 \frac{1}{3}$ to 8 inches across, color, bright scarlet, overlaid with bright orange. Foliage green.

Secetaire Chabanne-3 feet. Distinct and pleasing salmon; very free; a fine bedder.

\section{Bronze Foliage}

Dr. Budingen- 4 feet. One of the most brilliant scarlets, the individual flowers and trusses being both very large; beautiful bronze foliage.

King Humbert-4 feet. Flowers as large as those of the largest of the orchid flowering Cannas. Bright orange scarlet streaked with crimson. Foliage is bronze with brownish green stripes. A strong robust grower.

\section{Foliage Variety}

Robusta-8 feet. Probably the largest growing Canna in cultivation. If planted in rich soil will attain 7 to 9 feet in height. Foliage large and broad; color, rich metallic bronze green.

\section{DAHLIAS}

A. D. Livoni-A rich shell pink, double quilled flower of perfect form and very iree; grand for cut flowers.

Arabella-A show Dahlia. Light sulphur yellow shaded peach-blossom on edges.

Black Beauty-A grand dark maroon variety of distinct form and great beauty.

Earon Schroeder-A large Decorative Dahlia; rich glowing purple, light shading. 
Catherine Duer-A very large, new Decorative variety. Color, a bright, iridescent crimson scarlet.

Countess of Lonsdale-Cactus Dahlia. A peculiar but pleasing blending of salmon, pink and amber. Flowers freely under all conditions.

C. W. Bruton-A clear, rich yellow, perfectly double. One of the best yellow Decorative Dahlias.

Floradora-A dark, velvety crimson; Cactus in form.

Frank L. Bassett-Bright royal purple with blue shadings, large, finely formed flowers and a profuse bloomer.

Gen. Buller-The grandest fancy Cactus Dahlia. Color deep, rich, variety maroon tipped white. It is a very profuse bloomer. The flowers are borne on long, slender stiff stems and will keep a long time after being cut.

Cottysburg-An extremely large Decorative Dahlia, full, round, high center, bright, rich, pure scarlet. An early and extremely pnofuse bloomer for so large a flower.

Grand Duke Alexis-A quilled Dahlia, large, massive flowers, ivory white with a faint tinge rose at the extremities of the petals.

Kreimhilde-The color is an exquisite shade of shell pink, center petals white, outer pink, a profuse bloomer, erect and splendid for cut flowers.

Lyndhurst-One of the best bright scarlets; invaluable for cutting; large, perfectly full centers, with long stems.

Mrs. Winters-Very large, finely formed Decorative Dahlia, pure snow white.

Nymphaea-The most delicately beautiful of the Decorative Dahlias. Color clear, light shrimp pink, tinting lighter towards the center.

Queen Victoria-A beautiful, profuse, deep yellow.

Storm King-A grand, snow white Dahlia, blooms early and constantly, long stems, fine for cut flowers.

(The above 10 cents each.)

Twelve of the foregoing and one of the following for only $\$ 1.25$.

Jack Rose-A brilliantcrimsom-red with fiery tones in the center of the flower, the whole overlaid with a soft violet-maroon. "Decorative" type, double to the center never showing the yellow stamens or immature green. The flowers are from five to six inches across under normal conditions. 
Madam van Den Dael-A grand decorauve variety of immense size and beautiful form. Color, shell pink, with deeper markings.

Mrs. Roosevelt-Larger than the Grand Duke Alexis, better color, more graceful in form and splendid stems for cutting; flowers perfectly double while the color is a delicate pink, shading to a clear pink.

Professor Mansfield-A grand Fancy Decorative Dahlia, a sturdy grower with long stiff stems; color a clear yellow, clear white tips, and rosy red towards the center; a unique and handsome variety.

Souv. de Gustave Doozan-A handsome Decorative variety of immense size. Color a beautiful red, producing flowers from 6 to 8 inches in diameter, borne on long stems, well above the foliage.

Virginia Maul-Delicate shade of shell pink: it certainls is the coming commercial light pink Dahlia.

(The abore six 25 cents each)

\section{GERANIUMS}

\section{Staudard Varieties}

Named, 1 c and $20 \mathrm{c}$ each, $\$ 1.00$ and $\$ 2.00$ perdoz.

\section{Double}

Alphonse Ricard-Dwarf, vigorous habit; large green foliage; flowers of good size; a profuse bloomer; color, bright rermillion scarlet, good for beding and pots.

Jean Viaud-Brilliant rose pink with white throat; a continual bloomer, dwarf habit; an excellent pot rariety.

La Favorite-One of the best double whites; flowers of large size; a continuous bloomer; fine foliage; a good bedding plant.

Miss F. Perkins-Color, light pink with white throat; clean, healthr foliage; constant bloomer. Unsurpassed as a bedder.

Mme. Charrotte-Dwarf, rigorous habit: foliage heavy, deep green, broad chocolate zone, flowers a deep, clear, rosy salmon and enormous in size.

Mme. Landry-A free and constant bloomer; florets large and on long stems; large folisge, heavy chocolate zone; color a brilliant apricot 8 almon; habit semi-dwarf and rigorous. 
S. A. Nutt-This is the standard dark red Geranium, more generally used than any other as a pot plant and for bedding. Brilliant deep acarlet; a compact, vigorous grower.

\section{Single Geraniums}

Eugene Sue-Magnificent, well formed flowers, produced in enormous trusses. The color is a brilliant shade of russet orange; foliage large and of fine texture; habit luxuriant, semidouble and robust.

Jacqueire-Beautiful, deep cardinal red; very vigorous and unsurpassed as a bedder.

L'Aube-Pure snow white; large round florets; magnificent trusses; a free bloomer and excellent habit of growth; a splendid bedding or pot variety.

Mrs. E. G. Hill-Enormous trusses of large florets; color a rosy salmon; habit strong and vigorous, attractively zoned; stands the sun perfectly.

\section{Standard Ivy-Leaved Varieties}

Casar Frank-The most popular Ivy Geranium ever introduced. The color is a magnificent shade of soft, rich crimson. The flowers are double and produced on long stems. Foliage is a waxy, rich green; habit rigorous and pleasing. For baskets it is striking and all that can be desired.

Joseph Warren-Rich, deep, rosy pink; large and handsome flowers; strong grower.

\section{Variegated Foliage Varieties}

Happy Thought-Center of leaf creamy white with broad margin of rich green. A distinct and beautiful variety.

Silver-Leaved S. A. Nutt-Treen, edged with white; strong and free bloomer, color a brilliant crimson scarlet.

\section{Scented Leaved Varieties}

Apple Lemon Nutmeg Rose




\section{EVERBLOOMING ROSES}

\section{On Own Roots}

Strong two-year-old rose plants $25 \mathrm{c}$. each; $\$ 2.60$ dozen. Unless otherwise stated.

One-year-old plants, in March and April, at half the price of two-year-old plants.

American Beauty-H. T. A hardy everblooming rose of immense size. Color a brilliant rose carmine shaded with rich crimson. $40 \mathrm{c}$ each; $\$ 4$ dozen.

Anteine Revioro-H. T. $A$ handsome rose of vigorous habit and growth. Color, rosy flesh on a yellow ground, shaded with a border of carmine.

Bessio Brown-H. T. Large blooms, perfect in shape, lasting splendidly when cut. Color, snow white, faintly tinged with pink. A fine, free and strong grower.

Blumenschmidt-T. Pure citron-yellow; outer petals edged tender rose. A sport from Mademoiselle Francisca Kruger, which it resembles in form. Winner of three firat premiums. $\Lambda$ wonderful yellow rose. We believe it to be the only good yellow bedding rose up-to-date. $35 \mathrm{c}$ each; $\$ 3.50$ per dozen.

Bridesmaid-T. A deep pink. As a cut flower it is cultivated more than any other rose.

Brido-T. The most besutiful white Tea rose. Flowers large and double on long stif stems. Last well when cut.

Catherine Mermet-T. One of the finest roses grown. Fault tess in form and charming in every shade of color from the purest silvery rose to the most exquisite combination of yellow and rose.

Cornelia Cook-T. Buds are beautiful, of immense size and borne on long stems. Flowers snowy white, buds the largest of any white roses.

Dr. Grill-T.-A copper yellow, medium ized flower.

Duchesse de Brabrant-T. Soft light rose with heavy shading of amber-salmon.

Etolle de France-H. T. A strong, vigorous grower with handsome, green bronzy foliage, and exceedingly free flowering. Flowers are large and borne on long, stiff stems. Color a lovely shade of clear red-crimson velvet. Very fragrant and keeps well.

Etolle de Lyon-T.-The finest yellow bedding rose for outside planting. A hardy free bloomer. 
General McArthur-H. T.-A red Rose that is already a fixture in many gardens. The shape is fine; color brilliant scarlet. We advise trying this Rose. 40c each; $\$ 4$ dozen.

Golden Gate - T. - A strong healthy grower; long pointed buds, opening to a flower of large, creamy white, tinged with yellow and rose.

Gruss an Teplitz-China-A rich dark crimson, changing to a velvety red. A strong grower and continuous bloomer.

Helen Good-T. This is a true Cochet Rose. The color is a delicate yellow, suffused with pink, each petal edged deeper, very chaste and beautiful. $35 \mathrm{c}$ each; $\$ 3.50$ a doz.

Helen Gould - H. T. One of the finest everblooming roses. ('olor, a soft intense carmine with shades of cerice. Blooms freely.

Hermosa-(China) Best pink bedder. First and mast perpetual bloomer in existence.

Kaiserin Augusta Victoria-H. T. A continuous bloomer producing successive crops of buds. Pure snowy white. $35 \mathrm{c}$ each; $\$ 3.50$ per dozen.

Killarney-H. T. Said to be the finest pink rose ever produced; coloring, a deep shell pink, flowers enormous in size, the petals being frequently two and one-half inches deep. 40c each; $\$ 4.00$ per dozen.

La France-H. T. No variety can surpass this in delicate coloring - a silvery rose shaded with pink. It blooms continuously and is hardy. First-class in every respect.

Maman Cochet-T. A very vigorous grower with rich, healthy foliage. The extra large flowers produced on long stems are very double and buds and half expanded flowers are exquisite in form, color and fragrance. Deep rose pink, shaded with yellow.

Marie Guiliot-T. Perfect in form: flowers large and double to the center. Holds first place among white tea roses in purity of color, depth of petals and queenliness of shape. A healthy grower.

Marie Van Houtte-T. A fine straw yellow color, outer petals tinged with pink. Grows vigorously, blooms freely and is very fragrant. A superb rose.

Meteor-H. T. A velvety red everbloomer of the deepest glowing crimson. Flowers medium size, very double. A free bloomer.

Papa Gontier-T. Large, long blooms with thickbroad petals of dark carmine crimson.

My Maryland-H. T. An American Rose that has jumped into popular favor at once, sweeping the decks clean of Europe and America. Color glowing in tense pink; large, full and of fine form. The freest rose in growth and bloom that we know. 50c each; $\$ 5.00$ per dozen. 
Olivia-H. T. The ideal red bedding rose; it has more petals in it than Geneal McArthur and is a shade lighter in color than Rhea Reid, but has them both backed off of the boards when it comes to free blooming. A superb rose. 40c each ; $\$ 4.00$ per dozen.

Perle de Jardins-T. A grand yellow rose. Splendid for cut flowers. Extra fine.

President Taft-This rose was raised in Cincincinnati, the home of President Taft. It is without question the most remarkable of all pink roses. It has a shining, intense, deep pink color possessed br no other rose. It is a fine grower, free bloomer, gond size and form, fragrant and in a class by itself as to color. It seems impossible to say too much in faror of this rose. 35c each; $\$ 3.50$ per dozen.

Rhea Reid-H. T. This is the new red forcing Rose originated by E. G. Hill. Flower large and double, very free blooming and exquisitely fragrant, rich, dark, velvety red. The best of all red garden Roses to date. 35c. each; $\$ 3.50$ per dozen.

Richmond-H. T. Best red forcingrariety yet produced. Of strong and rapid growth. Produces freely throughout the year. Long, pointed buds on tall, straight stems with elegant dark foliage. Very fragrant. $35 \mathrm{c} \mathrm{each;} \$ 3.50$ per dozen.

Safrano-T. A strong grower and an old favorite. A bright apricot color changing to orange fawn.

Sunset-T. Flowers large and double, very fragrant; plants free flowering. Coloring rich, a strong yellow with rich orange and chrome yellow in the center. 35c each; $\$ 3.50$ per doz.

White Killarney-H. T. All growers of Killarney will be glad to grow the pure white sport from it. It forces, and we beliere today is unequalled for this purpose among the whites. Be sure and try it. Is just as fine in the garden as Killarney. 40c. each; $\$ 4.00 \mathrm{doz}$.

White Mamon Cochet-T. Vigorous in growth with rich, healthy foliage, producing large flowers of purest white.

Winter Gem-A beautiful tea rose and a wonderful bloomer. Color an exquisite shade of pink.

Wm. R. Smith, or Maiden's Blush-T. The soft blending of the salmon-pinks and the rosepinks and the beautiful flesh tints in this Rose give a singular resemblance to the entrancing flush on a maiden's cheek. A grand garden Rose. 35c each, $\$ 3.50$ per dozen.

Yellow Mamon Crochet-T. Color a good sulphur yellow on first opening, changing to a delightful rose shade. Blooms large and perfectly double; splendid form and freely produced. An ideal bedder. 


\section{Hybrid Perpetuals}

Captain Christy---H. P. Delicate peach blow pink, center richer in color, large and full. Abroad this rose is classed with the Hybrid Teas. 35c each; $\$ 3.50 \mathrm{doz}$.

Frau Kari Druschki-H. P. Snow white, very large. full and perfectly formed; superb. This is the standard by which all white roses are judged. 60c each, $\$ 6.00$ per dozen.

Gen. Jacqueminot-H. P. Bright red, fragrant, extra.

Paul Neyron-H. P. Deep, shining rose; flowers very large. A strong grower with almost thornless stems. Free bloomer.

\section{Everblooming Climbing Koses.}

Climbing Killarney-Cl. H. T. An exact counterpart of Killarney in every respect except that it is a vigorous climber. This will prove a great garden Rose. 35c. each; $\$ 3.50$ a doz.

c. La France-Cl. H. T. Identical with La France, except its climbing habit. Pink.

c. Meteor-Cl. H. T. The brightest colored of all roses. A free, persistent bloomer and a very rapid grower. The acme of all red climbers.

c. Pearl of the Garden-Cl. T. Deep golden yellow. Vigorous grower.

c. Wooton-Cl. H. T. Flowers a bright Magenta red, passing to velvet crimson. Blooms profusely and is a strong, rampant climber.

Gainsborough $-\mathrm{Cl}$. H. T. A rose of the greatest merit. Enormous in size. A beautiful pink.

Marechal Nell-Cl. T. A deep sulphur yellow; full, large and fragrant. Finest yellow rose in existence. A climber in habit and very desirable in the South. 40c. each; $\$ 4.00$ dozen.

Mrs. R. Peary-C1. H. T. Grandest of all white climbers. Only pure white, hardy, everblooming rose. A strong. rapid grower. Flowers are grand, being large, full, deep and double, and produced on long, stiff stems.

Pillar of Gold-Cl. T. The color is a deep yellow, flushed with coppery yellow. Reverse of petals shows touches of bright rose. The blooms are double to the center, of the largest size and come in immense sprays or bunches of from five to ten blooms on a single branch. A perfect gem. $35 \mathrm{c}$ each; $\$ 3.50$ per doz.

Reine Marie Henriette-Cl. H. T. An excellent crimson-flowered, everblooming climber. Flowers are exquisitely formed; full and double; tea scented; strong growing and very free blooming. 


\section{Ramblers}

Baby Rambler - (Polyantha) - New dwarf everblooming Crimson Rambler. Grows to height of 18 inches and is in bloom all the time; flowers in clusters of brightest crimson. A most wonderful rose.

White Baby Rambler (Catherine Ziemet)-(Pol.) This is the far famed white flowering Baby Rambler. Certainly a sight worth seeing when in full bloom. Pure white.

Crimson Rambler-Cl. Pol. The greatest of all climbing roses.

White Rambler-Cl. Pol. Pure pearl-white flowers.

Yellow Rambler-Cl: Pol. Fine golden-rellow flowers.

Pink Rambler.-Wich.- Dorothy Perkins. A most beautiful shell pink; the flowers are borne in large clusters of small double blooms and rery sweetly scented; quite first-class.

\section{HARDY SHRUBS AND TREES}

\section{Acer. The Maples}

Acer dasycarpum-Silver Maple-A large tree with spreading branches and pendulous branchlets. Leaves deeply 5-lobed, the divisions again lobed and toothed, bright green above, silvery white beneath, turning pale yellow in autumn. The fruit ripens usually before the leaves appear. Widely cultivated and a grand tree. 50c and \$1.00.

A. Platanoides-Norway Maple-25c, 50c, 75c and $\$ 1.00$ each.

A. saccharum, Sugar Maple-A large, stately tree of upright, dense habit, thriving in almost any soil. Leaves 3- to 5-lobed, dark green on upper, pale on the lower surface, turning in autumn to brilliant shade of scarlet orange and vellow. A grand street and lawn tree. Tỏe and $\$ 1.00$.

\section{Albizzia. The Mimosa Tree}

Albizzia Julibrissin (Mimosa Tree)-A remarkably beautiful and floriferous tree developing a low flat-topped crown. Everywhere associated with Southern gardens, and londIng to them, by graceful feathery follage and acacia-like flowers of pink and yellow, a subtle and lasting charm. Hardy as far north as Washington and Memphis.

$25 \mathrm{c} ., 50 \mathrm{c}$ and $75 \mathrm{c}$ each. 


\section{Althea}

25 and $50 \mathrm{c}$ each.

Among the most beautiful hardy flowering shrubs for lawns and gardens.

Althea Amplissima-Double pink.

A. Pompone Rouge-Double red.

A. La Reine-Double white.

A. Totus Albus-Single, pure white.

A. Meehanii-Leaves variegated with creamy white; flowers lavender with a purple blotch at the base of the petals.

\section{Amorpha}

A. Frutiscosa-False Indigo-A branching shrub usually 6 to 8 feet tall. Leaves compound, consisting of 11 to 25 bright green leaflets. Flowers violet-purple, disposed in clustered racemes 3 to 6 inches long. $50 \mathrm{c}$ each.

\section{Berberis. The Barberry}

Berberis Thunbergi, Thunberg's Barberry-A graceful shrub of low, dense habit. Leaves entire bright green, assuming in autumn dazzling tones of orange, scarlet and crimson. Berries brilliant red, borne in great profusion, and persisting throughout the winter. One of the most beautiful shrubs in cultivation. $25 \mathrm{c}$ and $50 \mathrm{c}$ each.

\section{Buddleia variabilis. Butterfy Bush}

B. v. veitchiana. A beautiful rariety. Flowers violet-purple, orange throat. Almost a continuous bloomer during summer. $25 \mathrm{c}$ each.

\section{-Calycanthus. The Strawberry Shrub}

Calycanthus Floridus - An old favorite, with double, chocolate colored,"strawberry scented flowers. 25c and 50c each.

C. praecox-The Oriental Sweet Shrub. Yellow flowers in winter and early spring. Very fragrant. 50c each.

\section{The Catalpa 'Tree}

Catalpa Speciosa (Western Catalpa). The flowers trusses of this species are very large and full, really gorgeous in effect; so strongly are they contrasted against the bright green and luxuriant foliage. Splendid as a specimen trae for the lawn. 50c and $75 \mathrm{c}$ each.

C.!Bignonoides. The Indian Beam. 25c each. 


\section{Cercis. The Red Bud Tree}

Cercis Canadensis-Red Bud. A small tree with a wealth of floral beauty. Leaves heartshaped, deep rich green, fading with tones of bright. clear yellow. Flowers produced in early spring, almost concealing the branches, borne in clusters of four to eight, of a beautiful rose pink color. One of the best of the flowering trees. 50c each.

\section{Chionanthus. The Fringe Tree}

Chionanthus virginica-White Fringe-A shrub or low tree the stout branches forming an oblong narrow head. Leaves ovate, dark green, turning yellow early in autumn. Flowers appearing when leares arc almost grown, white, in loose, drooping panicles. Fruit blue, resembling a small plum. The flowers are exceedingly feathery and graceful. $50 \mathrm{c}$ and $75 \mathrm{c}$ each.

\section{Cornus. The Dogwoods}

Cornus Floridus-An ornamental, spreading irregular shaped tree, producing large white flowers in spring and rich crimson foliage in autumn. $50 \mathrm{c}$ each.

C. f. rubra-Red flowering dogwood. A rare variety, the flowers of which are a rich, rosy red. $\$ 1 . .00$ each.

\section{Corylus. The Hazels}

Corylus avellana-Filbert. A large shrub, 10 to 12 feet, tall, with heart-shaped dark green leaves. Nuts large, embraced in short, fringed husk, with sweet edible kernels. \$1 each.

\section{Cydonta. The Japanese Quince}

\section{Cydonia Japonica - Flowering Quince}

- The glory of this old-fashioned, time-honored shrub, radiant with its garland-decked branches in early spring, is not dimmed by the competition of fairest rivals, so exclusive is its type of beauty. With extreme hardiness and durability formost in its list of attributes, no better plant could be $s e-$ lected for border or garden planting, or for informal or clipped hedges. The form with the bright scarlet flowers is most popula:.

$25 \mathrm{c}$ and $50 \mathrm{c}$ each.

\section{The Deutzia}

\section{$25 \mathrm{c}$ and $50 \mathrm{c}$ eack}

A family of profuse flowering shrubs. Generally hardy, and well adapted to most soils. Useful for shrubberies, groups or specimens, and the smaller kinds are also desirable for forcing. 
Delitzia Crenata-A vigorous grower with double pure white flowers, borne in panicles.

D. Rosa Plena-Double pink flowers. Exceeding ly dainty and beautiful.

D. Pride of Rochester-Double white flowers with under side of petals rose. Very robust.

D. Gracilis-An old-fashioned, dense shrub; blooms in shaded places as well as in sunny ones. A charming species of dwarf habit. Flowers pure white; graceful and pretty.

\section{Elaeagnus. The Deciduous Oleásters}

Elaeagnus longipes. Silver Thorn. Of low growth. Leaves silvery; flowers yellow, hanging in wreaths along the branches and followed by a thick brilliant fruitage of scarlet berries in July, that are edible as wull as ornamental. $50 \mathrm{c}$ each.

\section{Forsythia. The Golden Bells}

Familiar hardy shrubs that burst into bloom as winter is leaving. The bright golden yellow, starlike flowers wrap themselves along the naked branches in a wealth of bloom that is especially bright and cheerful at such an early season. They easily attain a height of eight feet, and are ornamental in leaf as well as in flower. $25 \mathrm{c}$ and $50 \mathrm{c}$ each

\section{Gymnocladus. The Coffee Tree}

Gymnocladus dioicus-Kentucky Coffee TreeA large tree with stout, slightly spreading branches, forming a narrow round head. Leaves compound, the leaflets ovate, dark green at maturity, turning bright yellow in autumn. Flowers in terminal racemes, nearly white; pods 6 to 10 inches long. reddish brown with a glaucus bloom. 25c each.

\section{The Hydrangens}

85c, 50c and $\$ 1.00$ each.

Grand free-flowering shrubs with large clusters or panicles of showy flowers. They are admirably adapted for border planting, either as specimen plants or in masses. A moist, fertile soil, with full or partial exposure to sun, is best adapted to their requirements.

Hydrangea Paniculata Grandiflora-Large Flowered Hydrangea. Undoubtedly the most popular variety and one of the showiest shrubs in cultivation. The flowers are almost all ray-like and sterile, and are produced in very large panicles. When fully expanded the flowers are white, but soon assume tones of rose and bronze on the exposed sides. This shrub requires severe pruning in early spring to insure the largest trusses. 
H. Arborescens Sterillis-Hills of Snow. A form of the Wild Hydrangea with all of the flowers ray-like and sterile, resembling a snow-ball. $\Lambda$ handsome floriferous hardy shrub, literally loaded with dazzling white flcwers, and continuing to blossom for a large part of the summer.

H. Hortensis-Japanese or Garden Hydrangea Beautiful shrubs with dark glossy green foliage and very showy flowers. They are not hardy north, unless afforded a great deal of protea tion, but extensirely grown as pot or tub-plants and frequentiy used for decorating piazzas and formal gardens. The color of the flowers seemingly varies in diferent solls, ranging from white to shades of blue and pink. Flowers in globular clusters, all of them ray like and sterile. The following are the varieties offered:

Otaksa-Handsome clusters of pink or blue flowers. Avalanche-Huge clusters of white flowers.

\section{Hardy Jasmines}

Jasmine nudiflorum-The Winter Jasmine. A graceful shrub with quadrangular drooping branches. Leares compound, consisting of three leaflets, dark green. falling in late autumn. Flowers bright yellow, opening very early in spring or on warm days in winter. $25 \mathrm{c}$ and $50 \mathrm{c}$

J. officinale-This variety has pure white fragrant flowers.

J. revolutum-Italian Yellow Jasmine.

Juglans. The Walnut Trees

Juglans regia-English Walnut-This is the tree that produces the large, thin shelled walnuts of commerce. $40 \mathrm{c}$ each.

J. sieboldiana-Japanese Walnut-A tree in habit and foliage similar to Heart-shaped Japanese Walnut. Nuts somewhat thickershelled, not conspicuously flattened, the kernels sweet and edible. Deserves to be widely cultivated. both for nuts and ornament. Perfectly hardy. 25c and $50 \mathrm{c}$ each.

J. niger, Black Walnut-A native tree of large size and majestic form, beautiful foliage. Tree is a rapid grower, producing a large round nut of excellent quality. 25c and j0c each.

\section{Kerria Japonica}

Kerria Japonica-The Globe Flower-A graceful shrub of medium height, with green bark and with double jellow flowers from June to October. $25 \mathrm{c}$ each.

\section{Lagerstroemia. The Crape Myrtle}

A very popular and free flowering ahrub or small tree, which produces blooms in great abundance 
throughout the summer. The flowers are beautifully fringed and are borne in great clusters. A massing of these or a single specimen makes a most striking effect. We offer three varieties: Pink, crimson, and purple. 25c, 50c, 75c and $\$ 1.00$ each.

\section{Syringa. The Lilacs}

25 and $50 \mathrm{c}$ each.

With the revival of old-fashioned gardens the popularity of these shrubs is increasing. No shrubbery mass is complete without them. They are hardy, robust plants that do well and flower abundantly with little care.

Common Lilac-The well known old-fashioned Lilac so often seen in gardens. It is hardy and vigorous; endures neglect and blooms abundanty. The bluish purple flowers are very attractive and useful for decorations.

Common White-Ita general character is similar to the above. Flowers white.

\section{Liriodendron. The 'Tulip Tree}

Liriodendron tulipifera-Tulip Tree-A large and stately rapid-growing tree with narrow pyramidal crown. Leaves 4-lobed, bright green and lustrous, turning yellow in autumn. Flowers cup - shaped, resembling a tulip,greenish yellow, blotched with orange. A handsome tree and one that is deserving of the highest esteem of planters. $25 \mathrm{c}, 50 \mathrm{c}$ and $\$ 1.00$ each.

\section{Lonicera}

Lonicera Morrowi-First Breath of Spring-A shrub with wide spreading branches, 4 to 6 feet tall. Flowers pure white, changing to yellow, sweetly fragrant, freely produced in early spring. The bright red berries which bend the heavy laden shoots in summer are simply gorgeous. Highly commended. 25c, 50c and $\$ 1.00$ each.

\section{Paulownia. The Empress Tree}

Paulownia Imperialis-A rapid growing tree, with very large leaves, and in spring bears large panicles of light blue, very fragrant flowers. An exellent shade tree. $50 \mathrm{c}$ and $75 \mathrm{c}$ each.

Japanese Persimmon

Hiyakume is one of the best of the Japanese varieties, 4 to $5 \mathrm{ft}$. high, $50 \mathrm{c}$ each.

\section{Philadelphus. The Mock Oranges}

$25 \mathrm{c}, 50 \mathrm{c}$ and $\$ 1.00$ each

Well known shrubs that are prized for their beautiful foliage and white lowers. The taller 
kinds flower profusely, and nothing is finer in their season. While the dwarf rarieties do not bloom so lavishly they form pretty, compact bushes. Useful for the front of shrubberies.

Philadelphus Coronarius (Garland Mock Orange)A vigorous, hardy old favorite, of erect, compact habit. Fragrant, early, white flowers.

P. Grandiflorus-Forms a large spreading bush with graceful, drooping branches. A strong grower. Flowers white. A very desirable shrub.

\section{Populus-The Poplars}

Populus carolinensis, Carolina Poplar-A symetrical and very rapid growing tree, making an upright or pyramidal head. Most popular and widely planted species. 50c, 75c and $\$ 1.00$ each.

P. nigra fastigiata. Lombardy Poplar-A tall. columnar tree of picturesque and very formal aspect. One of the characteristic trees of Lombards and other parts of Italy. A rapid growing and hardy tree. 50c $75 \mathrm{c}$ and $\$ 1.00$ each.

\section{Platanus. 'The Plane Tree}

Platanus orientalis-Oriental Plane-A large and massive tree with a very wide, round-topped head. Bark whitened, exfoliating, lending a picturesque aspect, especially in winter. Cultivated from time immemorial and today one of the best street trees. Very hards. To cents each.

\section{Punica}

Punlca granatum - Pomegranate. - A splendid shrub with large double flowers, variegated red and sellow. 25c each; $\$ 2.50$ per dozen.

\section{Rhus Cotinus. The Smoke Tree}

Greatly admired for its cloud-like masses of very delicate flowers which appear the last of April and cover the entire plant during the summer. From a distance the plant appears like a cloud of moke. $25 \mathrm{c}$ and 50c. each.

\section{Melia. The China Tree}

From 25c to $\$ 2.00 \mathrm{each}$

\section{Umbraculiformis The Texas Umbrella Tree}

A subvariety of the China Tree; of remarkably fast growth; very symmetrical, resembling an umbrells in shape. One of the handsomest deciduous trees; cannot be surpassed as a shade tree. Adapted throughout the Southern States. From 25c to $\$ 2.00$ each. 


\section{Salix. The Willow Tree}

Salix Babylonica Dolorosa-Wisconsin Weeping Willow-A very hardy variety, withstanding the winters of the far North. The leaves are whitened on the lower surface. 50c and $\$ 1$ each.

\section{Spiraea. The Spireas}

$$
25 \mathrm{c}, 50 \mathrm{c} \text { and } \$ 1.00 \text { each }
$$

Spirea Anthony Waterer-One of the most beaul tiful shrubs in cultivation. Dwarf habit; carmine crimson flowers. Used as an edging to shrubberies.

S. Bumalda-Flowers rosy pink, in large flat clusters. Foliage good and vigorous. Desirable as an edging to shrubberies.

S. Albiflora-Dwarf White Spirea. A low dense shrub with stiff, upright branches. Native of Japan. Leaves lancelott, bright green,' with incised or serrate borders. Flowers white, in numerous flat-topped clusters in summer. Neat and attractive.

S. Multiflora-Of dwarf habit; flowers clear pink. The best very early flowering spirea.

S. Prunefolia Flora Plena-A hardy, old-fashioned shrub that is still very popular. As the leaves are opening small, snow white, double flowers wrap themselves along the branches in a lavish display of bloom. The little glossy leaves color brilliantly in autumn. Makes an elegant hedge and is useful anywhere.

S. Reevesiana-Attractive foliage and beautiful clusters of pure white florets which bend the branches gracefully and cover them completely.

S. Reevesiana Flora Plena-Similar to the above in every way excepting flowers, which in this case are very double.

S. Thunbergii-A graceful bush, beautiful at all seasons, with innumerable small white flowers that crowd along its slender branches and shine as snow through the light green feathery foliage. The tiny leaves turn a brilliant orange scarlet in the autumn.

S. Van Houttei-Among the very finest of flowering shrubs. A strong, hardy grower of grace. ful, drooping habit with handsome foliageThe profusion of bloom weighs the slender branches and covers the bush with a beautiful canopy of white. Desirable from any standpoint.

S. sorbiafolia stellipeda-Ash-Leaved Spirea-The white flowers are produced in immense pyramidal panicles, frequently ten inches wide by fifteen inches high; these backed with the bright green ferny foliage, appear like large bouuuets of blooms. Flowers during July and August- Strong plants, 50c each. 
This is the beautiful Japanese Storax. Strong plants, 4 to $5 \mathrm{ft}$. high, $75 \mathrm{c}$ each.

\section{Symphoricarpus}

Symphoricarpus racemosus-The Snowberry-A well known dwarf shrub with small pink flowers and large white berries that hang on the plant the greater part of winter.

S. vulgaris-Indian Currant-Similar to above, but with bright red fruit. $25 \mathrm{c}$ each.

\section{Tilia. The Linden Tree}

Tillia A merican-American Linden.-A large tree, forming a broad round topped crown. Leaves broadly oval or heart-shaped, dark green above pale green beneath, turning yellow in autumn. Flowers creamy white, opening in summer. A grand tree, suitable for streets, lawns or parks. $50 \mathrm{c}, 75 \mathrm{c}$ and $\$ 1.00$.

\section{Ulmus. The Elm Tree}

Ulmus Americana-American Elm-A large and stately tree with long and graccful branches. Leares oblong, shapely serate, dark green, turning pale yellow in autumn. Very picturesque in age and desirable for lawn or landscape. $25 \mathrm{c}, 50 \mathrm{c}$ and $\$ 1.00$ each.

U. racemosa, Cork Elm-One of the Elms best adapted to the South, reaching a height of upwards of 100 feet, with oblong rounded top. Branches provided with corky wings, and clothed with dark green foliage. A valuable shade tree. 50c each.

\section{Vibnrnum. The Snowballs .}

25 and $50 \mathrm{c}$ each.

In this group are included the snowballs, which give in spring the same showy effect produced by hydrangeas in the fall. Viburnums are especially hardy, grow quickly and are invaluable in shrubbery borders.

Viburnum Opulls Sterlle-Snowball or Guelder Rose; a grand, hardy shrub with handsome showy flowers produeed in large globular clusters. An old-time favorite.

V. Plicatum-One of the most ornamental shrubs. It bears abundant white balls of bloom that have a beautiful setting in the deep green leaver.

V. carlesi (New) An introduction from Korea producing its delicately scented flowers in May and June. The buds before expanding are of an attractive pink color and develope into Bouvardia-like umbrels of white flowers which last in a fresh condition for a long time; entirely distinct and most desirable. $\$ 1.00$ each. 


\section{Vitex. The Chaste Tree}

Vitex agnus castus-A graceful shrub, growing from 5 to 6 feet high, with dense skikes 6 to 8 inches long of ltlac colored flowers late in summer. $25 \mathrm{c}$ and $50 \mathrm{c}$ each.

\section{The Wegelias}

25 and $50 \mathrm{c}$ each.

Valuable for ornamental plantings. They thrive in any soil, and are strong growers and generally hardy. When young they are of upright habit, growing with age into graceful shrubs.

Wegelia Rosea-Rich, rose colored flowers. Strong grower.

W. Hibridi Eva Rathke-Flowers of dark carmine red; distinct and fine; one of the choicest Hybrid.

W. Variegata-A dwarf form with lesves bordered with yellow; flowers rose color.

W. floribunda-Flowers, a rich bright crimson. Very floriferous.

\section{HARDY VINES}

\section{Akebia Quintata. Akebia Vine}

One of the most graceful of our hardy climbers, with deep green foliage, and producing in early spring numberless bunches of violet-brown flowers, which have a pleasant cinnamon odor. $25 \mathrm{c}$ and $50 \mathrm{c}$ each.

\section{Ampelopsis Veitchi. The Boston Ivy}

A most satisfactory and beautiful climber. Entirely hardy anả can adapt itself to any locality or exposure. $2 E$ and $50 \mathrm{c}$ each.

\section{Ampelopsis Quinoquefolia}

The Well Known Virginia Creeper. 25 and 50c each.

\section{The Clematis Vines}

25 and $50 \mathrm{c}$ each.

Popular, hardy vines.

C. Paniculata-A strong, luxuriant grower, with light green foliage that is handsome in itself. Flowers star-shaped, white and fragrant. 


\section{Clematis Hibrida}

Large flowering Clematis.

40 and $60 \mathrm{c}$ each.

Clematis Duchess of Edinburg-Double like a rosette; fragrant, hardy and vigorous.

C. Jackmanii-The best known and most valued of this family. A perfect mass of bloom when in full flower. Color, dark, rich royal purple.

\section{Euonyuns. The Climbing Euonymus}

$25 \mathrm{c}$ and $\$ 1.00$ each.

Euonymous Radicans-C!imbing Euonymus-An evergreen species with small glossy leaves. Grows slowly to a height of 20 or 30 feet. Clings tenaciously to walls or rocks, for which it makes a splendid cover.

E. R. Variegata-Differs from the above in that it has pretty creamy white markings on the leaves that make it raluable for contrasts.

\section{The English Iry}

A familiar evergreen vine with thick, dark green leares. It grows in almost any soil and is fond of shady places. Much used to cover buildings, rocks, trunks of trees, trellis work, graves and as an evergreen carpet beneath trees in places where grass will not grow. $25 \mathrm{c}$ and $50 \mathrm{c}$ each.

\section{Pueraria. The Kudzu Vine}

An extremely rapid growing vine that has been known to make 40 or 60 feet of growth a year. It is an especially desirable thing for quick effects, and useful for hiding unsightly objects. The leaves are large and handsome. 10 and $25 \mathrm{c}$ each.

\section{Lonicera. The Climbing Honeysuckle}

Lonicera Japonica. Japanese Honeysuckle. - A rampant evergreen climber with stems 10 to 1 a feet long. Leares orate, dark green, densely covering the rine and branches. Flowers white changing to yellow, deliciously fragrant, borne in great profusion in summer and occasionally in the autumn. Grand for trellis and ground cover. $25 \mathrm{c}$ each.

\section{Rhynchospermum-The Jasmine Vine}

Rhynchospermum Jasminoides-A rery beautiful, hardy and rapid-growing evergreen climber. producing fragrant white flowers from April until July. When in full bloom this plant is most conspicuous. $25 \mathrm{c}$ and $50 \mathrm{c}$ each

\section{Tacoma. The Trumpet Vine}

This is a familiar, strong growing vine, with deep, rich green foliage, and large trumpet shaped 
flowers in early summer. It is very desirable for covering summer houses, training over arbors, and to climb over tree, rocks and rustic bridges. Will grow in almost any soil. 25c and 50c each.

\section{The Wistarias}

25 and 50c each.

Grand free-flowering vines with handsome showy flowers. They are among the best and hardiest ornamental vines, and are well adapted for training on porches, arbors or trellises. For their best development a deep, rich, loamy soil should be provided by trenching and enriching, for they amply repay for any favors of this kind. When established a greater profusion of blossoms may be secured by rather severe pruning, cutting back the lateral shoots to short spurs, but the gain in flowers is perhaps at the sacrifice of picturesque and natural grace and beauty.

Wistaria Chinensis-Chinese Wistaria. A rapid growing tall vine with handsome foliage and flowers. Leaves compound, consisting of about eleven pale green leaflets. Flowers pea shaped, purplish, profusely borne in dense drooping clusters 7 to 12 inches long, opening in midspring. Very showy and desirable.

W. Chinensis Alba-White Wistaria. A form of the above with pure white flowers.

W. Frutescens-American Wistaria. A tall and slender vine with dark green foliage, growing naturally from Virginia to Florida. Leaves compound, consisting of 9 to 15 leaflets, producing an airy light shade. Flowers lilac purple, in numerous dense short racemes, blossoming about three weeks later than the Chinese Wistaria.

\section{HEDGE PLANTS}

\section{Berberis Thunbergii}

Bears inconspicuous, creamy white flowers that ripen into scarlet fruit. The beautiful small green leaves open early in the spring; in autumn they turn a brilliant golden or scarlet hue. One of the most desirable hedge plants. $\$ 1.50$ per dozen; $\$ 10.00$ and $\$ 15.00$ per 100 .

\section{Citius Trifoliata-The Hardy Orange}

A small tree with green bark and numerous stout branches armed with strong, sharp thorns. Flowers white, fragrant, resembling those of the true orange; fruit golden yellow, about as large as a walnut; a very useful hedge plant and a remarkably attractive ornamental. 15c each, $\$ 10.00$ per 100 


\section{Ligusirum. The Privets}

Amoor River Privet-The best hardy evergreen and quick growing privet for hedges. Leaves small and pretty; flowers white, in tapering racemes. A fine ornamental shrub. First grade, $75 \mathrm{c}$ per doz.; $\$ 5.00$ per $100 ; \$ 45.00$ per 1000 . Second grade, 60c per doz.; $\$ 4.00$ per $100 ; \$ 35.00$ per 1000 . Third grade, 50c per doz.; $\$ 3.00$ per $100 ; \$ 2750$ per 1000 . Fourth grade. $40 \mathrm{c}$ per doz.: $\$ 2.50$ per 100 ; $\$ 2.50$ per 1000 .

California Privet-Dark green foliage, which is nearly evergreen, remaining on the plants until mid-winter. Free of growth and succeeds under the most adverse conditions. First grade, 60 c per doz; $\$ 4.00$ per $100 ; \$ 35.00$ per 1000 . Second grade, 50c per doz; $\$ 3.00$ per 100: $\$ 27.50$ per 1000. Third grade, 45̃c. per doz.; $\$ 5.50$ per $100 ; \$ 22.50$ per 1000 .

\section{Spirea Thumburgii-Snow Garland}

Of dwarf habit, branches slender and drooping; foliage very narrow, light green changing to bright orange and red in fall; flowers small, white, which appear very early in March and last three weeks. A beautiful variety for a dwarf or low-growing hedge. $\$ 2.00$ per dozen; $\$ 15.00$ per 100

\section{EVERGREENS}

\section{Abelia}

Abelia Grandiflora-Hybrid Abelia-One of the most beautiful shrubs in cultivation. The graceful arching stems are clothed with dark, glossy leaves, which are evergreen in South and tardily deciduous in the North. Flowers white, tinged with pink, about an inch long, borne in profuse clusters from early summer until checked by frost. 25c and $50 \mathrm{c}$ each.

\section{Berberis Japonica. Mahonia Japonica}

A dwarf shrub with shiny green prickly foliage and clusters of yellow flowtrs in May, followed by bluish berries. $50 \mathrm{c}$ each.

\section{Huxus. Boxwood}

The well known Boxwood, now so popular for planting as individual specimens on the lawn, in vases and window boxes, and for formal and decorative effects that can be produced by the many shapes into which this plant can be trimmed.

Pyramidal-shaped, $2 \mathrm{ft}$. high_____ $\$ 2.00$

Bush-shaped, 2 ft. high

Bush-shaped, 18 ins. high

Bush-shaped, 15 ins. high 


\section{Thuya. The Arborvita}

These highly ornamental trees are appropriate for small lawns as well as larger areas. They are generally hardy; grow vigorously in varied soils and are easily transplanted. They are useful in grouping, bedding, bordering and for hedges, screens and house decoration.

Thuya Occidentalis, American Arborvitae. A tree of variable height and pyramidal outline, especially beautiful when young. Foliage bright green, yellow-green beneath, or in winter assuming tones of brown and bronze. Both this species and the following are used in tubs, vases or jardinieres for winter decoration of porches, vestibules, etc. As garden plants they are very pleasing, some of the formal varieties lending striking effect. 25c per foot.

T. Orientalis, Oriental Arborvitae-A low, bushy tree of columnar or pyramidal habit, native of Asia. Foliage bright green in summer, assuming tones of bronze and brown in winter. Both the typical form and the varieties following are very useful as garden plants, and in tubs or vases, as porch plants. Very hardy and beautiful. 25c per foot.

T. Orientalis Compacta, Compact Oriental Arborvitae. A low and very compact form, with bright green foliage. Very formal and attractive, and a favorite everywhere. 50c per foot.

T. Orientalis aurea nana, Golden Arborvitae-Of a very dwarf and compact habit; a perfect gem for small gardens. $75 \mathrm{c}$ per foot.

\section{The Evergreen Euonymus}

Euony mus Japonicus-An erect form with glossy green foliage and bright green bark. Used for individual planting and also for hedges. 25 and $50 \mathrm{c}$ each.

\section{Juniperus. The Junipers}

Juniperus hibernica-Irish Juniper.-A slender columnar form with numerous upright branches, very closely appressed. Very formal in outline and invaluable in Italian gardens and where architectural features are desired. Foliage glaucous green. 50c. per foot.

\section{Laurocerasus. The Laurel Tree}

L. laurocerasus, English, or Cherry Laurel-A small tree or bush with handsome, shining foliage. Flowers white, in numerous short racemes, expanding in April or May. Requires protection North of Washington and Memphis. 25c and 50c each. 


\section{Ligustrum. The Evergreen Privet}

Ligustrum Sinense (Chinese Privet)-A tall and graceful shrub with dark green and gloss s leares, fully erergreen in the south. Flowers in profusion in late spring or earls summer, creamy white, disposed in numerous fluffy panicles. Berries blue-black with an iridescent bloom, literally covering the branches, which bend in willowy outlines with the burden of their loads. Really grand for informal groups or as specimen plants. 25c each.

\section{Magnolia Grandiflora}

A broad-leared erergreen. The flowers are deep broad cups of waxen white, deliciously fragrant, and bloom when the tree is quite roung. 5 ve per $\mathrm{ft}$.

\section{Retiuospora. The Cypress Tree}

Retinospora Plumosa -(Japanese Crpress)-One of the most valued of all Japanese Cypresses. A rapid-growing rariety with exquisite. plumelike foliage and slender branches. Very handsome. $75 \mathrm{c}$ per foot.

\section{Picea.-The Spruces}

Picei Plungens Glauca. Colorado or Koster's Blue Spruce-A noble variety and one of the most valuable for ornamental planting. A vigorous grower with stiff, close branches and brilliant, rich silvery blue foliage. Perfectly hardy under all condition. $\$ 2.00$ per font.

P. Excelsa, Norway Spruce-This familiar Spruce is more generally useful than any of the others. It is a rapid grower; does well in most soils, and withstands the bleak, cold winds of winter. It is valued highly for shelters, windbreaks, or hedges. If left untrimmed it spreads out magnificently. If pruned, it bo comes a stately tree of symmetrical form. $\$ 1$ per foot.

P. Canadensis (P. Alba) White Spruce-Vatire tree of dense habit, ranging from Labrador to Alas$k a$, and south to Montana and New York. Foliage light bluish green, exhaling a strong aromatic odor when bruised. Cones glossy brown, 1 to 2 inches long, attractive and shapely; \$1.t0per foot. 


\section{HARDY PERENNIALS}

\section{Achillea, the Pearl}

Achillea Ptarmica Flor Pleno-Double-Flowered White Tansy. A free flowering herb with a profusion of small white flowers almost throughout the entire season. It is a garden form of the European White Tansy and grows 1 to 2 feet tall. It is valuable for cut flowers and on account of its remarkable floriferous character is one of the most popular hardy perennials. $15 \mathrm{c}$ and $25 \mathrm{c}$ each.

\section{Bellis}

Bellis Perennis, English Daisy-Admirably adapted for edgings, borders, and low beds; also well suited for growing in pots. Flowers, shaded from white to a glowing red shaded with rose. $10 \mathrm{c}$ each.

\section{Carnations}

Giant Hardy, Perpetual Flowering-Blooms profusely and continuously. Plants thick and bushy, bearing immense double blossoms of perfect regularity and very fragrant. Mixed colors. $10 \mathrm{c}$ each; $\$ 1.00$ per dozen.

\section{Convallaria. The hily of the Valley}

For best results this old favorite should be planted in March or April. 10c each; 40c dozen.

\section{Aquilegia. The Columbines}

This hardy perennial luxuriates in the moister situations in the garden where it forms permanent clumps. growing from $1 \frac{1}{2}$ to 2 feet high. The large, unique, long spurred flowers, gracefully hung on long stems, are not only brilliantly effective on the plant, but equally as desirable when cut for vase and house decoration. $15 \mathrm{c}$ each.

\section{Digitalis. The Fox Glove}

These are very showy plants for the garden. They are very easy to grow and produce long spikes standing 4 to 5 feet high, well furnished with large flowers of various colors; including white, cream, rose, red and other shades, all of which have beautiful throat markings of purple, maroon, etc. $15 \mathrm{c}$ each.

\section{Dicentra. The Bleeding Heart}

Dicentra Spectabilis (Bleeding Heart)-An oldtime favorite with clustered stems 1 to $2 \mathrm{ft}$. tall. Leaves compound, glaucous green, with numerous rather broad segments. Flowers large and heart-shaped, deep rosy red, nodding in graceful drooping racemes. A beautiful plant, rich in sentiment and associations with the old home gardens. $15 \mathrm{c}$ and $25 \mathrm{c}$ each.॰ 


\section{Funkia--Day Lilies}

Funkia Lancifolia (Narrow-Leaved Day LilyLeaves lanceolate, the blades 4 to 6 inches long and 1 to 2 inches wide, densely clustered. Flowers pale lilac, borne in long racemes. 1.jc and $25 \mathrm{c}$ each.

F. Subcordata (White Flowered Day Lily-Leaves heart-shaped, strongly, many ribbed, flowers white, 4 to 6 inches long, erect or ascending, disposed in long leafy spikes. 15 and $25 \mathrm{c}$ each.

\section{Graillardia}

Showy and free bloomers, flowers profusely all summer. They are good bedders; very beautiful; fine for bouquets or for cutting for house decoration. $15 \mathrm{c}$ each.

\section{Geum}

Pretty border plants, growing about 18 inches high and producing showy, bright scarlet flowers the greater part of the summer and fall. Fine for bouquets. $15 \mathrm{c}$ each.

\section{Gypsophila}

Free bloomers for rock work or shrubbery; will grow in any soil; tine for bouquets. 15c each.

\section{Hibiscus}

Hibiscus Crimson Eye-Hardy Hibiscus; a fine large, single white flower with crimson eye. Perfectly hardy and robust. 25 and $50 \mathrm{c}$ each.

\section{Hollyliock}

These stately old fashioned perennials are most striking when seen in groups or long rows against evergreen hedges, shrublery, etc., and in their turn form a fine back ground for plants of lower growth. Flowers are of all shades and colors. ranging from pure white through almost every conceivable shade of yellow, red and rose to almost black.

In separate colors or mixed. Two-year plants, 15c

\section{Lavend ula}

Lavendula vera. True Lavendar-The sweet fragrant Lavender is an old garden favorite of easy culture, producing numerous terminal spikes of "lavender"' blue flowers. A much branched plant 2 to 3 feet tall, densely leafy. The narrow leaves, often.with tufts of smaller ones in their axils, are silvery downy with revolute entire borders, persistent or nearly so. Thrives best in a light well drained soil, freely exposed to the sun.

$10 \mathrm{c}$ and $25 \mathrm{c}$ each.

\section{Iriope}

Liriope Graminifolia (Opheopogon SpiculatusPurple Snake Beard. A very pretty plant with grass-like foliage, growing in dense tufts. Flowers lavender or violet purple, borne in dense spikes in summer. $25 \mathrm{c}$ each. 
L. variegata. A variety of the above with beautiful variegated foliage and lavender flowers; splendid for baskets, urns ard window boxes. $25 \mathrm{c}$ each.

\section{Paeonia. The Peonies}

These old-time favorites are being planted more than ever before. Their great flowers are perfectly formed and are often as fragrant and as delicately colored as a rose. Grow about 2 feet high.

Red

Pink

White

Phlox. The Perennial Phloxes

10c each. $\$ 1.00$ dozen.

These are considered the most desirable of all hardy perennials; flowering abundantly from July until late in the autumn. They delight in sunny locations and rich soil, but are not particular.

Alceste-Deep violet, shading almost to blue.

Athis-Deep, clear salmon. Some claim this to be the most showy variety in cultivation.

Coquelicot-The finest and brightest red of all the Phlox. The color is a bright orange scarlet.

Indpendence-An excellent large flowering, early, pure white. None better.

Lothair-Clear, even carmine; deep crimson өye.

Maculata-Tall growing, many branched, pyramidal trusses of bright reddish, almost royal purple. The freeest and most showy in permanent border.

Pantheon-Large, clear, deep bright pink; a charming variety.

R. P. Struthers-Color, clear cherry red, suffused with salmon shades; deep red eye, fine large truss.

\section{Rudbeckia. Golden Glow}

This is decidedly one of the brightest and most showy among the hardy plants, and one of the easiest culture possible, commencing to bloom in July and continuing until killed by frost. The plant grows from 5 to 7 feet high, producing numerous stems which are laden with double yellow flowers. Excellent when cut. 15c each.

\section{Shasta Daisy}

This has long been considered one of the best hardy perennials for permanent garden decoration. It is of compact bushy growth, bearing in profusion throughout the season white flowers of immense size, often more than 4 inches across, on stems $1 \frac{1}{2}$ to 2 feet long. $15 \mathrm{c}$ each. 


\section{Statice. Sea Larender}

Beautiful for winter bouquets. Pretty little flow. ers which ought to be in all gardens. $15 \mathrm{c}$ each.

\section{Stokesia Cyanea}

This is a rare and beautiful hardy perennial. It grows about 2 feet high and bears from 20 to 30 handsome lavender-blue, corn flower like blossoms. In bloom from July till frost. One of the choicest subjects for the hardy border and for cutting.

$15 \mathrm{c}$ each.

\section{Sweet William}

An attractive, free flowering, hardy perennial, producing splendid effect in beds and borders. 10c each.

Double Crimson. Double White.

\section{Miscellaneous Plants}

\section{Ageratum}

Imperial-Dwarf in growth; true blue and always in bloom. An excellent bedding plant. je each; 50e doz., \$3.75 per:00.

\section{Alternanthera}

A. Aurea Nana-Best yellow; forms a low bushy plant with green foliage, marked brightly with yellow. Splendid for borders and bedding. 5c each, 50c doz., $\$ 3.75$ per 100 .

A. Paryonchoides Major-Best bright red; like the abore only foliage is green with red.

\section{Aloysia Citridora. Lemon Verbena}

An old favorite with delightfullr scented leares. A sprig of it is often included in mixed bouquets. The leares when dried will retain their fragrance for years.

\section{Alyssum}

The well known plant used for edging. White flowers. 5c each, 50c per doz.. \$3.75 per 100.

\section{A parasu*}

\section{$25 \mathrm{c}, 50 \mathrm{c}$ and $\$ 1.00$ each}

Asparagus Plumosus Nanus-This graceful plant has foliage finer than the most delicate fern; an ercellent house plant. 
A. P. robusta. Like the above except that it is a vigorous climber.

A. Sprengeri-Invaluable as a decorative plant: most useful to furnish greens for decorating as it retains its freshness for considerable time after being cut.

\section{Asters}

Giant Comet (Ostrich Plume)-Plants attain the height of eighteen inches, each bearing many large flowers on long stems. je each, 50 c per doz., \$3.75 per 100 .

\section{BEGONIAS}

\section{5 cents each}

B. Alba Picta-A flowering Begonia with leaves 2 to 3 inches long with bright silver spots on the upper side.

B. Dewdrop-This is a grand variety with white flowers.

B. Fobosa-This is one of the most graceful of all the Begonias. The foliage is small and fleshy. Bright pink flowers.

B. Robusta-Bright rose and pure white; coral red buds. This is a very desirable variety.

B. Rubra-One of the finest Begonias in cultivation Its dark, glossy, green leaves, combined with its free flowering habit make it one of the very best plants for house or conservatory decoration. The flowers are a scarlet rose color.

B. Thurstonii-A Begonia with grand foliage.

B. Vernon-A fine bedder; clear rose flowers.

B. Rex-Valuable for the grand and varied marking of the leaves,

\section{Carnations}

Florists carnations for winter flowering. 10 c $; \$ 1.00$ per dozen.

\section{Coleus}

The varieties offered below are the standard sorts for bedding, and for filling baskets, vases and window boxes:

Firebrand-Brilliant reddish brown.

Golden Bedder-Fine yellow.

Queen Victoria-Crimson, golden edge.

Lord Palmerston-Dark crimson.

Verschaffelti-Bright crimson.

$10 \mathrm{c}$ each $; \$ 1.00$ per dozen; $\$ 4.00$ per 100 . 


\section{Cosmos}

An autumn blooming plant, producing fiowers in white, pink and red shades, and furnishing: an abundance of cut flowers. je each, $50 \mathrm{c} \mathrm{doz.}$

\section{Cypenrus Alternifolius. The Umbrella Plant.}

An excellent plant for growing in water and in damp places; makes a very ornamental house plant, always presenting a green and attractive appearance. $10 \mathrm{c}$ and $25 \mathrm{c}$ each.

\section{Dusty Miller}

A splendid edging and bedding plant with fine cut silvery foliage. jc each, 50c dozen. $\$ 3.00$ per 100

\section{Fuchsia. Lady's Eardrops}

A well known plant of easy culture for the houes or shady places in the garden. $10 \mathrm{c}$ and $25 \mathrm{c}$ each.

\section{Gardenia. The Cape Jasmine}

Gardenia Jasminoides - Cape Jasmine. This beautiful flowering shrub is again becoming very popular. The double wax-like flowers which are exquisitely fragrant, are greatly in demand for button-hole bouquets. $15 \mathrm{c}$ and $50 \mathrm{c}$ each.

\section{Heliotrope}

A half hardy perennial. flowering during the whole season; its delightful perfume makes it a desirable cut flower. Dark blue. jc, 10c and $25 \mathrm{c}$ each.

\section{Hibiscus Rosa Sinensis}

A magnificent plant for bedding or pot culture. In this section they should be bedded in open ground in April and potted off in Octoper. The flowers are produced continuously during the entire summer. $25 \mathrm{c}, 50$ and $75 \mathrm{c}$ each

Hibiscus Decorus-Single rose.

H. Peach Blow-Flowers are double and of a charming rich, clear pink color, with a small, deep crimson center.

H. Miniata-Virid red; double. Very beautiful.

H. Sub-Violaceus-Crimson violet; double 


\section{FERNS}

25c, 50c and $\$ 1.00$ each

Boston-This fern has for years been the most popular house plant in cultivation.

Pierson-A new form of Boston fern. The pinnae subdividing make miniature fronds which are superimposed on the main frond and look as if two or three were condensed in one. They are graceful beyond description.

Nephrolepsis Piersoni Elegantissima-This is a sport from the Pierson fern in which the plumy peculiarity of the original form is even more distinctly developed than in the original. The plant is of much more compact habit and while it grows only one-half as tall the fronds are nearly twice as wide, making it a much more desirable plant.

Nephrolepsis Scotti-A compact, dwarf form of the Boston Fern. It is just as gracefully drooping in habit of growth but is more compact.

Nephrolepsis Whitmani-This is an aristocrat among all the Nephrolepsis, and when well grown is unquestionably the finest of the lot. The leaves being more deeply divided than the elegantissima giving the plant a more graceful appearnce, while another important point in its favor is that not a single frond has ever reverted to the common Boston fern.

Maiden Hair-Very graceful and dainty ferns. Suitable for growing in pots as house plants.

Dwarf Fern-For fern dishes. Assorted varieties. 10 c each; $\$ 1.00$ per dozen.

\section{Selaginella Emilliana}

A new moss with feathery stems branching from the base and forming a dense tuft. Used with ferns in ferneries. 10c. each.

\section{Hydrangea Hortensis}

For Pots and Tubs

$$
\text { 25c, 50c and up }
$$

Beautiful shrubs with dark glossy green foliage ind very showy flowers. They are not hardy north. unless afforded a great deal of protection, but extensively grown as pot or tub plants and frequently used for decorating piazzas and formal gardens. The cblor of the flowers, which are globular clusters, ranging from white to shades of pink when grown in pots or tubs. The following varieties are offered:

Otaksa-Handsome clusters of pink flowers.

Thos. Hogg-Huge clusters of white flowers. 


\section{Impatiens}

Impatiens Sullivan-This makes a very shapely plant, and is in bloom continuously the year round, outdoors or indoors, even in the small plants three or four inches high. It blooms so profusely as to almost cover the entire plant; blooms, rosy carmine. Very desirable. 10 each.

\section{Ipomea. The Moon Vine}

The most rapid growing of all climbing vines. Flowers immense and pure white, opening in the evening and closing about noon of the following day. $10 \mathrm{c}$ each, $\$ 1.00 \mathrm{doz}$.

\section{Kenilworth Iry}

Lavender and purple flowers. A charming, neat trailing plant, suitable for baskets. $5 \mathrm{c}$ each, $50 \mathrm{c}$ dozen

\section{Lantana.}

\section{5 each, 50c dozen}

Lantana-Perfectly at home in the open border, growing luxuriantly and blooming profusely.

L. Weeping-One of the best basket plants grown. The plant has a most graceful, drooping habit. grows very rapidly and blooms continually, summer and winter, producing large clusters of the most delicate lilac and rosy-pink.

\section{Nasturtium}

Dwarf, mixed colors, 5c each, 50c dozen.

Tall, mixed colors, 5c each, 50c dozen.

\section{Pansy}

Large flowering variety. इc each, 50c dozen, $\$ 3.75$ per 100 .

\section{Salvia. The Scarlet Sage}

S. Splendens-A rich flowered bedder. Potted plants $5 \mathrm{c}$ each, 50c doz., $\$ 3.75$ per 100 . Seed bed plants $25 \mathrm{c}$ dozen, $\$ 2.00$ per 100 .

S. S. Bonfire-The freest blooming of all, seemingly on fire all the time, with dense, flaming spikes $2 \frac{1}{2}$ feet high. Potted plants $5 \mathrm{c}$ each, $50 \mathrm{c}$ per dozen. $\$ 3.75$ per 100 . Seed bed plants $25 \mathrm{c}$ doz., $\$ 2.00$ per 100 .

\section{Senecio Scandens}

Parlor Ivy-Indispensable climber. For vases, baskets or boxes. $10 \mathrm{c} \mathrm{each} ; \$ 1.00 \mathrm{doz}$. 


\section{Tradescantia. Wandering Jew}

Silver Queen-A useful trailing plant for hanging baskets, window boxes, etc., with bright green foliage striped with silvery white.

$10 \mathrm{c}$ each, $\$ 1.00 \mathrm{doz}$.

\section{Verbena}

There are no plants more satisfactory for summer blooming than these. Specially suited for vases and window boxes, flower beds and borders. Blue, white and scarlet. 5c each, 50c doz.; $\$ 3.75$ per 100 .

\section{Vinca Major Variegata}

This is a beautiful and variegated trailing vine, admirably adapted to hanging baskets and vases. The leaves are a glossy and green broadly margin. ed with creamy white; flowers blue. $10 \mathrm{c}$. and $25 \mathrm{c}$. each.

\section{Violets}

10c. each; $\$ 1.00$ per dozen.

California-Single; blue.

Lady Hume Campbell-Double, blue, sweet scented.

Swanely White-Double, very fragrant. 


\section{Bulbs for Spring Planting}

\section{Caladium Esculentum}

Elephant's Ear-Grand tropical-looking plant. A favorite for specimens on the lawn, or for bordering large sub-tropical groups. In deep, rich soil, if freely watered, they produce enormous leaves, frequently 4 feet long by 3 feet wide. Height, 4 to 5 feet. 10c., 15c., and $25 \mathrm{c}$

\section{Gladiolus}

Gladiolus-They deserve to be grown in every garden. For cutting they are invaluable, the flowers lasting in water a week. They are of easy culture, grow in any garden soil, never fail to flower the same season, and by successive plantings every two or three weeks, from April to June, can be had in flower from July until checked by frost. "The bulbs are easily kept in a paper bag on any convenient shelf until planting time. 3c. each; 20c. per dozen; $\$ 1.50$ per 100. Extra fine, 5c. each; 30c. per dozen; $\$ 2.25$ per 100 .

\section{Madeira Vine Bulbs}

The old favorite, "Climbing Mignonette." So much prized for porches and arbors, on account of its rapid growth and freedom from insects. Thick, glossy leaves, and long, hanging stems of teathery, fragrant white flowers. Price, 5c. each; 5ic. per dozen; $\$ 3.75$ per 100.

\section{Tuberoses}

One of the most fragrant and popular of the summer flowering bulbs.

Excelsior Pearl-Double white. $3 \mathrm{c}$ each, $25 \mathrm{c}$ doz. $\$ 1.75$ per 100 . 


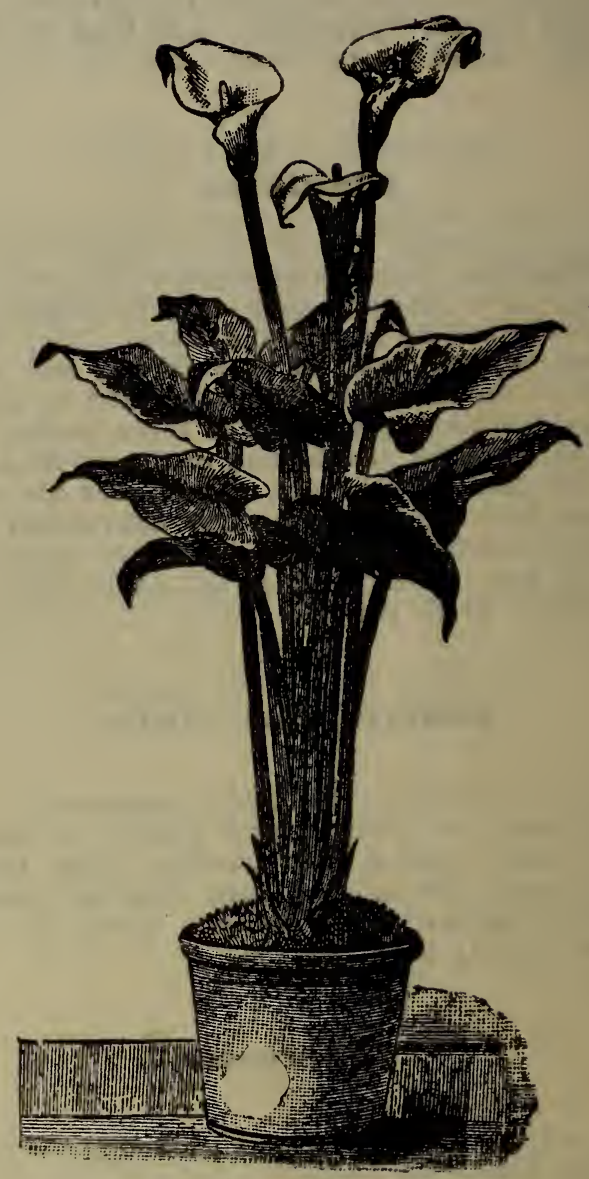

